\title{
Ram-induced growth of ovarian follicles and gonadotrophin inhibition in anoestrous ewes
}

\author{
S. Atkinson and P. Williamson \\ School of Veterinary Studies, Murdoch University, Murdoch, Western Australia 6150, Australia
}

\begin{abstract}
Summary. Southdown ewes in mid-seasonal anoestrus were exposed to rams for $0 \mathrm{~h}$ (control group), $2 \mathrm{~h}, 24 \mathrm{~h}, 40 \mathrm{~h}, 3$ days, 10 days or 20 days. Serial blood samples were then taken to determine LH and FSH levels. Ewes with $>24 \mathrm{~h}$ ram exposure were ovariectomized immediately after bleeding, and all follicles $>1 \mathrm{~mm}$ diameter were dissected from the ovaries and measured. $\mathrm{LH}$ basal concentrations and pulse frequency increased significantly within $2 \mathrm{~h}$ of ram introduction, but by $24 \mathrm{~h}$ fell, and then remained low. FSH concentrations fell within $2 \mathrm{~h}$ of ram introduction and remained low. Control group ewes (isolated) had no follicles $>4 \mathrm{~mm}$ diameter, whereas all ewes exposed to rams had large follicles, with $\mathrm{CL}$ or preovulatory follicles present at $40 \mathrm{~h}$ after ram introduction. Ram introduction was also associated with follicle recruitment (antrum formation to $<2 \mathrm{~mm}$ ). Follicular recruitment and development to the large follicle stage therefore occurred during a period of low plasma gonadotrophin levels and suppressed LH pulsing.
\end{abstract}

\section{Introduction}

The introduction of rams to seasonally anoestrous Merino ewes stimulates ovulation within 6 days and oestrus after about 3 weeks (Underwood, Shier \& Davenport, 1944; Schinckel, 1954). Oldham, Martin \& Knight (1978) and Oldham (1980) showed that plasma luteinizing hormone (LH) concentrations in anoestrous Merino ewes increased within $10 \mathrm{~min}$ of the introduction of a ram, and an LH surge typical of oestrus occurred $24-40 \mathrm{~h}$ later, followed by ovulation. Ewes of British breeds are known to undergo a deeper, more prolonged seasonal anoestrus than Merinos (Martensz, Baird, Scaramuzzi \& Van Look, 1976). Chesworth \& Tait (1974) reported an increase in plasma LH levels in Border Leicester $\times$ Scottish Blackface ewes within $2 \mathrm{~h}$ of the introduction of the ram at the start of the breeding season. Edgar \& Bilkey (1963) found that the introduction of a ram to anoestrous Romney ewes 1 month before the onset of the natural breeding season resulted in a fertile oestrus about 22 days later, and they suggested that a silent ovulation had occurred within 5-6 days of ram introduction, followed by a normal oestrus 17 days later.

The present study was undertaken to determine the effect of the introduction and continuing presence of a ram on ovarian activity and plasma gonadotrophin concentrations in seasonally anoestrous ewes.

\section{Materials and Methods}

Animals. Southdown ewes in mid-seasonal anoestrus were run on irrigated kikuyu (Pennisetum clandestinum) pastures and were isolated from rams for 3 months before the start of the experiment. The control group $(\mathrm{N}=11)$ was isolated from rams throughout the experiment whereas a ram harnessed with a marker crayon was run with the remainder of the ewes from the beginning of the experiment. These ewes were randomly divided,into groups which were run with 
the ram for the following periods before blood sampling: $2 \mathrm{~h}(\mathrm{~N}=6), 24 \mathrm{~h}(\mathrm{~N}=6), 40 \mathrm{~h}(\mathrm{~N}=5), 10$ days $(\mathrm{N}=5)$ and 20 days $(\mathrm{N}=11)$.

An additional group of 6 ewes was exposed to a ram for 3 days, then isolated from the sight or smell of rams for a further 17 days (limited exposure) before blood sampling and ovariectomy were undertaken. This group served to demonstrate whether any effects seen in ewes $\mathbf{2 0}$ days after ram introduction were due to the initial stimulus or the continued presence of the rams. On the day before the end of the designated period of ram exposure, all ewes were fitted with jugular cannulae. On the following day blood samples were collected into heparinized vacutainers every 15 min for 6 or $9 \mathrm{~h}$. Plasma collected from all blood samples was frozen and stored at $-20^{\circ} \mathrm{C}$ until hormone radioimmunoassays were performed. Immediately after the bleeding period the ovaries were removed from all ewes except those with short periods of ram exposure ( 2 and $24 \mathrm{~h}$ ). The intact ovaries were immediately placed in Minimum Essential Medium with Earle's salts and Hepes buffer (Flow Laboratories, North Ryde, Australia) at $4^{\circ} \mathrm{C}$ and all follicles $>1 \mathrm{~mm}$ in diameter were dissected from the ovaries and their size recorded. Follicles $<2 \mathrm{~mm}$ in diameter were classified as small follicles, $2-4 \mathrm{~mm}$ as medium follicles and $>4 \mathrm{~mm}$ as large follicles (modified from Carson, Findlay, Burger \& Trounson, 1979).

LH assay. A double-antibody radioimmunoassay (Oldham et al., 1978) as modified by Martin, Oldham \& Lindsay (1980) was used to measure LH concentrations in jugular plasma. All procedures were identical to those used by Martin et al. (1980) and were performed in the same laboratory. Mean non-specific binding was 3.9\%. Intra-assay coefficient of variation was $4.3 \%$ based on all samples analysed. Two plasma pools with $2.57 \pm 0.31$ and $3.52 \pm 0.30 \mathrm{ng} \mathrm{LH} / \mathrm{ml}$ were included in two sets of triplicates in every assay. Inter-assay coefficients of variation calculated from these plasma pools were $5 \cdot 2$ and $8.2 \%$ respectively. The sensitivity of the assay (twice the standard deviation above the zero standard) was $0.08 \mathrm{ng} / \mathrm{tube}$.

FSH assay. A double-antibody radioimmunoassay was used to obtain FSH concentrations in jugular blood, collected hourly. The assay was performed at Prince Henry's Hospital Medical Research Centre (Melbourne) using on-going procedures established by Salamonsen et al. (1973). Mean non-specific binding was $1.9 \%$ while the intra-assay coefficient of variation was $8.4 \%$ based on all samples analysed. Two internal standards (plasma pools) were included in each assay with non-specific binding measured for each pool. Their values were $8.58 \pm 0.3$ and $46.61 \pm 2.5 \mathrm{ng}$ $\mathrm{FSH} / \mathrm{ml}$. Inter-assay coefficients of variation calculated from these pools were 17.6 and $10.8 \%$ respectively. The sensitivity of the assay was $1.3 \mathrm{ng} /$ tube.

Logit-log transformations were applied to the standard curves of the LH assay data (Rodbard, 1974). The frequency of the release of LH was standardized in terms of the mean number of peaks per group over a 6-h bleeding period (Martensz et al., 1976). For the purpose of this study an LH pulse was defined as a rise in $\mathrm{LH}$ which occurred within $30 \mathrm{~min}$ and exceeded the $95 \%$ confidence limits of the basal LH concentrations (Goodman \& Karsch, 1980). The basal levels were calculated from all values not considered to be part of the pulse. The hormone data were analysed with an unpaired $t$ test.

The ovarian data were subjected to a Kruskal-Wallis multiple range test in which mean values were ranked to compute the significance of the difference between means (Nie, Hull, Jenkins, Steinbrenner \& Bent, 1975).

\section{Results}

\section{Hormone concentrations}

The concentrations of $\mathrm{LH}$ and FSH for ewes exposed to rams for various lengths of time are presented in Table 1. Within $2 \mathrm{~h}$ of the introduction of the ram, the basal concentration of LH increased significantly $(P<0.05)$. By $24 \mathrm{~h}$ after ram introduction the baseline $\mathrm{LH}$ values had 
Table 1. Gonadotrophin values for seasonally anoestrous ewes exposed to rams for various lengths of time

\begin{tabular}{|c|c|c|c|c|}
\hline $\begin{array}{l}\text { Duration of exposure } \\
\text { to ram before } \\
\text { sampling }\end{array}$ & $\begin{array}{l}\text { No. of } \\
\text { ewes }\end{array}$ & $\begin{array}{l}\text { Basal LH conc.* } \\
\text { (ng/ml) }\end{array}$ & $\begin{array}{l}\text { Mean no. of } \mathrm{LH}^{*} \\
\text { pulses } / 6 \mathrm{~h}\end{array}$ & $\begin{array}{c}\text { FSH conc. } \dagger \\
(\mathrm{ng} / \mathrm{ml})\end{array}$ \\
\hline 0 & 11 & $0.45 \pm 0.1^{a}$ & $2.22 \pm 0.7^{a}$ & $17 \cdot 33 \pm 3 \cdot 1^{a}$ \\
\hline $2 \mathrm{~h}$ & 6 & $1 \cdot 28+0 \cdot 2^{b}$ & $4.00+0.6^{b}$ & $7.58+1.7 b$ \\
\hline $24 \mathrm{~h}$ & 6 & $0.48 \pm 0.1^{\mathrm{a}}$ & $0.66 \pm 0 \cdot 2^{\mathfrak{c}}$ & $8 \cdot 13 \pm 4 \cdot 6^{b}$ \\
\hline $40 \mathrm{~h}$ & 5 & $0.49+0.0^{a} \S$ & $0.40 \pm 0.2^{c}$ & $5.62 \pm 1.4^{b}$ \\
\hline 10 days & 5 & $0.71+0 \cdot 1^{\mathrm{a}}$ & $1.00+0.3^{c}$ & $6 \cdot 80+1 \cdot 4^{b}$ \\
\hline 20 days & 11 & $0.44 \pm 0.0^{\mathrm{a} \S}$ & $0.68 \pm 0.3^{c}$ & $11.20 \pm 1.5 \mathrm{c}$ \\
\hline 3 days & 6 & $0.42 \pm 0.0^{\mathrm{a}} \S$ & $0.00 \pm 0.0 \mathrm{~d} \S$ & $4.28 \pm 0.8^{b}$ \\
\hline
\end{tabular}

Values are mean + s.e.m.

Values within columns with different superscript letters are significantly different $(P<0.05)$.

* Blood samples taken every $15 \mathrm{~min}$ for 6-9 h.

$\dagger$ Blood samples taken every $60 \mathrm{~min}$ for $6-9 \mathrm{~h}$.

$\ddagger$ Ovariectomized after 20 days.

$\S$ s.e. $<0.005$.

returned to pre-exposure levels, and remained low at all further bleedings. The mean number of LH peaks detected per 6-h bleeding period increased significantly $(P<0.05)$ by $2 \mathrm{~h}$ after ram introduction, but subsequent numbers $(24 \mathrm{~h}, 40 \mathrm{~h}, 10$ days and 20 days) were significantly less than $(P<0.05)$ those before ram introduction. No LH pulses were detected in any of the ewes subjected to limited ram exposure and sampled at 20 days.

FSH concentrations fell significantly $(P<0.05)$ by $2 \mathrm{~h}$ after ram introduction and remained significantly lower than control group values throughout the experiment. At 20 days after ram introduction FSH levels were significantly higher $(P<0.05)$ than levels measured at $2 \mathrm{~h}, 24 \mathrm{~h}, 40 \mathrm{~h}$ and 10 days, but were still significantly below control group levels. In the limited exposure group FSH concentrations were significantly lower $(P<0.05)$ than control group values and those of ewes sampled after 20 days of continuous ram exposure.

\section{Ovarian morphology}

As shown in Table 2, the control ewes had no large follicles although they did have significantly more medium-sized follicles than any other groups. The control ewes also had significantly fewer small follicles than any other group. Corpora lutea $(\mathrm{CL})$ were present only in ewes ovariectomized

Table 2. Ovarian structures dissected from the ovaries of seasonally anoestrous ewes exposed to rams for various lengths of time

\begin{tabular}{|c|c|c|c|c|c|c|}
\hline \multirow{2}{*}{$\begin{array}{l}\text { Duration of } \\
\text { exposure to } \\
\text { ram before } \\
\text { sampling }\end{array}$} & \multirow[b]{2}{*}{$\begin{array}{l}\text { No. of } \\
\text { ovaries }\end{array}$} & \multicolumn{3}{|c|}{ Follicles } & \multirow[b]{2}{*}{$\mathrm{CL}$} & \multirow[b]{2}{*}{ Total } \\
\hline & & $\begin{array}{c}\text { Small } \\
(<2 \mathrm{~mm})\end{array}$ & $\begin{array}{c}\text { Medium } \\
(2.4 \mathrm{~mm})\end{array}$ & $\begin{array}{c}\text { Large } \\
(>4 \mathrm{~mm})\end{array}$ & & \\
\hline 0 & 12 & $5 \cdot 50 \pm 0.9^{a}$ & $3 \cdot 42 \pm 0 \cdot 6^{a}$ & $0^{\mathrm{a}}$ & $0^{\mathrm{a}}$ & $8 \cdot 83 \pm 1 \cdot 1^{a}$ \\
\hline $40 \mathrm{~h}$ & 12 & $10.33 \pm 1.4^{b}$ & $1.92 \pm 0.3^{b}$ & $1 \cdot 16 \pm 0 \cdot 2^{b}$ & $0 \cdot 50 \pm 0 \cdot 2^{\mathrm{b}}$ & $13.83 \pm 1.5^{b}$ \\
\hline 10 days & 12 & $11.17 \pm 1.9 \mathrm{c}$ & $1 \cdot 50 \pm 0 \cdot 3^{c}$ & $1 \cdot 58 \pm 0 \cdot 2^{c}$ & $0^{\mathrm{a}}$ & $14.25 \pm 1.6$ \\
\hline 20 days & 12 & $8.50 \pm 0.9 \mathrm{~d}$ & $2.42 \pm 0.7^{b}$ & $1.17 \pm 0.3^{b}$ & $0^{\mathrm{a}}$ & $12.08 \pm 1.4^{c}$ \\
\hline 3 days ${ }^{*}$ & 12 & $6 \cdot 17 \pm 1 \cdot 3^{e}$ & $0.83 \pm 0.3^{\mathrm{d}}$ & $1.08 \pm 0.3^{\mathrm{d}}$ & $0^{\mathrm{a}}$ & $8.08 \pm 1.2^{\mathrm{d}}$ \\
\hline
\end{tabular}

Values are mean \pm s.e.m.

* Ovariectomized after 20 days.

Values within columns with different superscript letters are significantly different $(P<0.05)$. 
at $40 \mathrm{~h}$ after ram introduction: 4 out of 6 of these ewes had at least one CL and the other 2 ewes had follicles noticeably larger ( 15 and $10 \mathrm{~mm}$ in diam.) than in any other ewes. No functional or regressed $C L$ were present in ovaries dissected at 10 days or 20 days. Ewes sampled at $40 \mathrm{~h}$ and 10 days after ram introduction had the greatest number of small follicles and total ovarian structures. Ewes that were exposed to the ram for the 3 days and then ovariectomized on Day 20 had the least number of total structures in the ovary, with very few medium-sized follicles present.

\section{Discussion}

The present study has demonstrated several new facets of ovarian-pituitary interaction in the anoestrous ewe. The introduction of a ram to the anoestrous ewes initially led to an increase in the baseline concentrations of plasma LH and to an increase in the frequency of LH pulses. The phenomenon of increased LH activity and subsequent ovulation in anoestrous ewes following the introduction of a ram has been recorded by several investigators (Schinckel, 1954; Edgar \& Bilkey, 1963; Oldham et al., 1978; Martin et al., 1980) and has been termed the 'ram effect'. By $24 \mathrm{~h}$ of ram contact, however, the basal concentrations of LH returned to the control group levels. The mean number of LH peaks measured also decreased to below control group values in samples taken after $24 \mathrm{~h}$. In contrast to the initial increase in LH activity, FSH concentrations fell within $2 \mathrm{~h}$ of ram introduction, and remained below control group values for the remainder of the experiment. This depression of gonadotrophin concentrations after the initial stimulus of ram introduction may have been due to the negative feedback effect of oestradiol produced by the large follicles $(>4 \mathrm{~mm})$ which developed in the ovaries of all ewes in contact with rams. Legan, Karsch \& Foster (1977) have shown that elevated oestradiol concentrations depressed circulating LH values in seasonally anoestrous ewes.

Follicular development, maturation and ovulation was obviously initiated immediately after the ram was introduced as ovulation had occurred in 4 out of 6 ewes ovariectomized after $40 \mathrm{~h}$ ram contact, presumably in response to the initial rise in LH basal levels and pulse frequency. This observation is in accord with earlier reports that an LH increase is necessary for complete follicular maturation (McNatty, Gibb, Dobson \& Thurley, 1981). Corpora lutea were observed at $40 \mathrm{~h}$ after ram introduction but probably did not become fully functional, because CL were not evident in ovaries collected at 10 days.

The ovaries from the control group had only small and medium-sized follicles present and no $\mathrm{CL}$, whereas large follicles were present in ovaries collected from all ewes exposed to the ram. There is no published evidence that follicles attaining a diameter of $4 \mathrm{~mm}$ can persist for extended periods in the ovary of the ewe without regressing or undergoing further development. Indeed, there is considerable evidence that folliculogenesis and atresia is a continual process, with 3-4 small follicles entering a rapid growth phase each day and taking around 4 days to grow from 2 to 4-5 mm in diameter (Turnbull, Braden \& Mattner, 1977). In the present trial, large follicles continued to develop in the ovaries for at least 20 days in ewes exposed to the ram even for as little as 3 days. After the initial ram stimulus which led to ovulation, follicles continued to develop to the large follicle stage $(>4 \mathrm{~mm})$, even though FSH and LH levels were depressed. The stimulus for continuing growth of these large follicles is then presumably some factor other than increased gonadotrophin concentrations, but one which is triggered by the introduction of the ram.

The number of small follicles in the ovaries of all ewes exposed to the ram was greater than in the control groups and increased at $40 \mathrm{~h}$ and 10 days, suggesting continuing recruitment of small follicles through this period even though LH and FSH concentrations were low. The numbers of small follicles in the ewes given limited exposure to the ram were similar at 20 days to the numbers of small follicles in the ewes continuously exposed to the ram, although lower than the number of small follicles seen in the ewes run continuously with the ram at $40 \mathrm{~h}$ and 10 days. The number of medium-sized follicles in the limited exposure group was also much lower than in any other group, 
although large follicles were present in numbers equal to those found in the ovaries of ewes continually exposed to the ram. This suggests that the large follicles were arising from the diminishing pool of medium-sized follicles which in this group were not being replenished by growth of small follicles. In the ewes given limited exposure to the ram, therefore, follicular recruitment (antrum formation) and growth to large follicles continued after removal of the ram.

These results suggest an effect of the ram on the recruitment of small follicles and stimulation of growth of ovarian follicles to the large follicle stage, an effect mediated through means other than elevated gonadotrophin levels.

We thank Dr G. Martin and Mr G. Thomas of the University of Western Australia, Department of Animal Science and Production Hormone Laboratory, for help with the LH assay; Professor S. D. Bradshaw for the use of facilities in his department; Mr T. Gill for help with the FSH assay; Dr C. Hawkins for help with the statistical analysis of the data; and Dr F. Sumbung and $\mathrm{Mr}$ W. Ayliffe for technical help.

\section{References}

Carson, R.S., Findlay, J.K., Burger, H.G. \& Trounson, A.O. (1979) Gonadotropin receptors of the ovine ovarian follicle during follicular growth and atresia. Biol. Reprod. 21, 75-87.

Chesworth, J.M. \& Tait, A. (1974) A note on the effect of the presence of rams upon the amount of luteinizing hormone in the blood of ewes. Anim. Prod. 19, 107110 .

Edgar, D.G. \& Bilkey, D.A. (1963) The influence of rams on the onset of the breeding season in ewes. Proc. N.Z. Soc. Anim. Prod. 23, 79-87.

Goodman, R.L. \& Karsch, F.J. (1980) Pulsatile secretion of luteinizing hormone: differential suppression by ovarian steroids. Endocrinology 107, 1286-1290.

Legan, S.J., Karsch, F.J. \& Foster, D.L. (1977) The endocrine control of seasonal reproductive function in the ewe: a marked change in response to the negative feedback action of estradiol in luteinizing hormone secretion. Endocrinology 101, 818-824.

Martensz, N.D., Baird, D.T., Scaramuzzi, R.J. \& Van Look, P.F.A. (1976) Androstenedione and the control of luteinizing hormone in the ewe during anoestrus. J. Endocr. 69, 227-237.

Martin, G.B., Oldham, C.M. \& Lindsay, D.R. (1980) Increased plasma LH levels in seasonally anovular merino ewes following the introduction of rams. Anim. Reprod. Sci. 3, 125-132.

McNatty, K.P., Gibb, M., Dobson, C. \& Thurley, D.C. (1981) Evidence that changes in luteinizing hormone secretion regulate the growth of the preovulatory follicles in the ewe. J. Endocr. 90, 375-389.

Nie, N.H., Hull, C.H., Jenkins, J.G., Steinbrenner, K. \&
Bent, D.H. (1975) Statistical Package for the Social Sciences, 2nd edn. McGraw-Hill, New York.

Oldham, C.M. (1980) Stimulation of ovulation in seasonally or lactationally anovular ewes by rams. Proc. Aust. Soc. Anim. Prod. 13, 73-86.

Oldham, C.M., Martin, G.B. \& Knight, T.W. (1978) Stimulation of seasonally anovular Merino ewes by rams. I. Time from introduction of the rams to the preovulatory LH surge and ovulation. Anim. Reprod. Sci. 1, 283-290.

Rodbard, D. (1974) Statistical quality control and routine data processing for radioimmunoassays and immunoradiometric assays. Clin. Chem. 20, 1255-1270.

Salamonsen, L.A., Jones, H.A., Burger, H.G., Buckmaster, J.M., Chamley, W.A., Cumming, I.A., Findlay, J.K. \& Goding, J.R. (1973) A heterologous radioimmunoassay for follicle-stimulating hormone: application to measurement of FSH in the ovine estrous cycle and in several other species including man. Endocrinology 93, 610-618.

Schinckel, P.G. (1954) The effect of the presence of the ram on the ovarian activity of the ewe. Aust. J. agric. Res. 5, 464-469.

Turnbull, K.E., Braden, A.W.H. \& Mattner, P.E. (1977) The pattern of follicular growth and atresia in the ovine ovary. Aust. J. biol. Sci. 30, 229-241.

Underwood, E.J., Shier, F.L. \& Davenport, N. (1944) Studies in sheep husbandry in Western Australia. The breeding season of Merino, crossbred and British breed ewes in the agricultural districts. J. Dep. Agric. West. Aust. 21, 135-143.

Received 3 May 1984 